\title{
Determinants of Family Planning Methods among Eligible Couples in Rural Area of Ludhiana, Punjab
}

\author{
Kavisha Kapoor Lal', Dhruvendra Lal ${ }^{2}$, Charanjit Singh ${ }^{3}$ \\ ${ }^{1}$ Assistant Professor, Department of Periodontics, CDC Ludhiana, Punjab, India. \\ ${ }^{2}$ Assistant Professor and CMO, Department of Community Medicine, CMC Ludhiana, Punjab, India. \\ ${ }^{3}$ Senior Resident, Department of Pedodontics, Desh Bhagat Dental College, Mandi Gobindgarh, Punjab, India. \\ DOI: https://doi.org/10.24321/2349.2880.202111
}

\section{I $\quad \mathbf{N} \quad \mathbf{F} \quad \mathbf{O}$}

\begin{abstract}
Corresponding Author:
E-mail Id:

drdhruvlal@gmail.com

Orcid Id:

How to cite this article: Health. 2021;8(4):1-7.

Date of Submission: 2021-11-22

Date of Acceptance: 2021-12-09
\end{abstract}

Dhruvendra Lal, Department of Community Medicine, CMC Ludhiana, Punjab, India.

https://orcid.org/0000-0001-6973-9311

Lal KK, Lal D, Singh C. Determinants of Family Planning Methods among Eligible Couples in Rural Area of Ludhiana, Punjab. Ind J Youth Adol

\section{$\begin{array}{llllllll}\mathbf{A} & \mathbf{B} & \mathbf{S} & \mathbf{T} & \mathbf{R} & \mathbf{A} & \mathbf{C} & \mathbf{T}\end{array}$}

Introduction: National Programme for Family Planning started in India for the first time in 1952 and India was the first country in the world to have come up with any such programme. But still, the problem persists in some parts of India, especially the rural parts. India poses a great challenge with over half of its population in the reproductive age group with many who reside in rural parts ( $68.84 \%$ of India's population is residing in villages).

Method: This is a population-based, cross-sectional study undertaken in the rural area of Ludhiana, Punjab where all eligible couples were included in this study after taking their verbal consent.

Results: Contraceptive use significantly differed among couples who only had female child/ children and those who at least had one male child. The study found that tubectomy is the main method of contraception. It was found that the age of females at the time of marriage was significantly lower in Scheduled Caste (SC) and Backward Class (BC) families as compared to Non-scheduled Caste (NSC) ones.

Conclusion: The study found that the age of females, parity, and number of female children determined the family planning practices.

Keywords: Family Planning, Contraceptives, Eligible Couples, Prevalence

\section{Introduction}

National Programme for Family Planning began in India for the first time in 1952 and India was the first country in the world to have come up with any such programme. There have been many changes in the policy and actual programme over many years and attempts are being made to achieve population stabilisation goals along with promoting reproductive health and decreasing maternal, infant and child mortality and morbidity. ${ }^{1}$

As per the 5th National Family Health Survey (NFHS), India's population is stabilising and the total fertility rate is reducing in most of the states. NFHS- 5 data showed that in many states, except for Bihar, Manipur and Meghalaya, the TFR (Total Fertility Rate) is 2.1 or less, which suggests that most states have achieved replacement level fertility. ${ }^{2}$ But still the problem persists in some parts of India, especially the rural parts, which pose a great challenge with over half of its population in the reproductive age group and many who reside in the rural part ( $68.84 \%$ of India's population is residing in villages). ${ }^{3}$ According to a cross-sectional survey which was conducted in the rural part of Haryana, 
where about 600 married females between 15 and 44 years of age group were interviewed, it was found that $75 \%$ of the respondents had some knowledge regarding modern contraceptives and $59 \%$ of the couples were using contraceptive methods, with tubectomy being the most common method. ${ }^{4}$ According to a study conducted in Tamil Nadu, there was a $39 \%$ prevalence of unfulfilled need for family planning, with spacing as $12 \%$ and limiting as $27 \%$. The main reason which was cited for unmet need among the couples was low perceived risk of pregnancy, followed by fear of side effects of contraceptives, insufficient knowledge regarding contraceptives, male partners who were against the use of family planning methods, and certain medical reasons. $^{5}$

History and research prove that proper attention to family planning measures in places that have high birth rates can decrease hunger and poverty, enhance the socio-economic status and also reduce maternal mortality and under 5 mortality, apart from women empowerment, education and long term environmental sustainability. ${ }^{6}$

There are several factors owing to poor family planning in rural parts of India like inadequate awareness among male partners, denial of the rights of women for the choice of contraceptives, preference for a male child, family pressure to get the first baby soon, fear of permanent infertility and low libido among both genders, and cultural beliefs. ${ }^{7}$ Thus this study would focus on the family planning needs in the rural area which are not effectively covered by the Cafeteria approach strategy where a mix of all scientifically approved methods of contraception is put in a basket for people's choice.

\section{Objectives}

- To assess the prevalence of use of various family planning measures among all eligible couples

- To find an association between various variables with the use of contraceptive methods

- To find an association between various variables with different family planning indicators

\section{Material and Method}

This is a population-based, cross-sectional study undertaken in the rural area of Ludhiana, Punjab where all eligible couples were included in this study after taking verbal consent from them. The study was initiated in the year 2019-20 and the survey was done until all the eligible couples in the area were surveyed. Since this study was non-interventional, so ethical waiver was given by the institutional committee.

Contraceptive Prevalence Rate among eligible couples was found to be $75 \%$ as per the study conducted by Osborn JA et al. ${ }^{8}$ Assuming this prevalence with a margin of error of $5 \%$ and $95 \%$ confidence interval, the sample size was calculated.

The equation used for calculating sample size is as follows:

$\mathrm{N}=\mathrm{Z}^{2} \mathrm{P}(1-\mathrm{P}) / \mathrm{e}^{2}$

Where,

$Z=$ level of confidence $-95 \%$ (1.96),

$\mathrm{P}=$ prevalence of smoking, and

$\mathrm{e}=$ margin of error

The minimum sample size in this study is 289 . The unit of study is eligible couple and the total sample size is 390 .

\section{Inclusion Criteria}

Participants who were physically and mentally fit, gave consent for the study, and were residents of the surveyed locality were included in this study.

\section{Exclusion Criteria}

Participants who were physically and mentally unfit, did not give consent, or were non-permanent residents in the area surveyed, were excluded from this study.

Data were collected using interview technique in which sociodemographic information along with the type of contraceptive used was determined.

The results were reported as frequencies and percentages and the association between various variables and contraceptive use was assessed using Chi-square test. The investigator himself took care of the data and used MS Excel for the purpose of statistical analysis. The level of significance was fixed at $95 \%$ confidence interval.

\section{Case Definitions}

Eligible Couple: These were the couples who were married at the time of the study, with females in the age group of 15 to 49 years, and required family planning services. ${ }^{9}$

Couple Protection Rate (CPR): It is defined as the percentage of eligible couples who are effectively protected against pregnancy by approved methods of family planning, like oral pills, intrauterine device (IUD), sterilisation, or condom. ${ }^{1}$

Total Fertility Rate (TFR): The average number of children a woman would have at the end of her reproductive period if she was subject, during her whole life, to the fertility rates of a given period and if she was not subject to mortality. TFR is expressed as children per woman. The total fertility rate is the sum of the age-specific fertility rates for all women multiplied by five. ${ }^{10}$

\section{Results}

A total of 390 eligible couples from the rural parts of District Ludhiana enrolled in this study, among whom included $47.70 \%$ were from Non-Scheduled Caste (NSC), 36.2\% from Scheduled Caste (SC) and 16.4\% from Backward Class (BC) (Figure 1). 


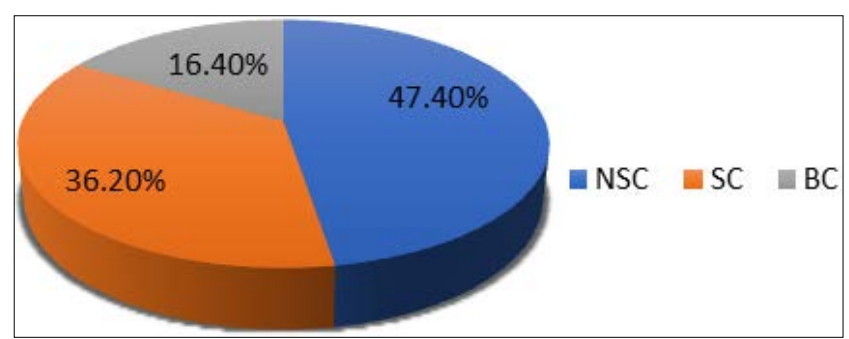

Figure I.Distribution of Eligible Couples according to Their Castes

The mean age of females in this study was 26.16 years (ranging from 17 years to 48 years). It was found that the maximum number of females belonged to the age group of $18-28$ years followed by $28-38$ years (Figure 2 ).

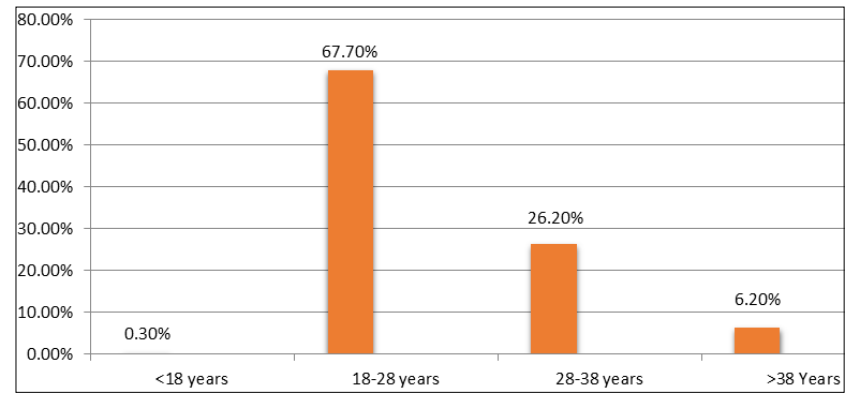

Figure 2.Age Range of Females in the Study

The mean number of children was 1.17 , with range between 0 and 6 . It was also found that there was a maximum of 3 stillbirths with an average of 0.02 . The average number of male and female children born to eligible couples in this study were 0.64 and 0.53 respectively (Table 1 ).

Table I.Demography of Eligible Couples

\begin{tabular}{|c|c|c|c|c|c|}
\hline Variables & $\mathbf{N}$ & Min. & Max. & Mean & $\begin{array}{c}\text { Std } \\
\text { Deviation }\end{array}$ \\
\hline $\begin{array}{c}\text { Age of wife } \\
\text { (years) }\end{array}$ & 390 & 17 & 48 & 26.16 & 5.705 \\
\hline Parity & 390 & 0 & 6 & 1.17 & 1.271 \\
\hline Stillbirth & 390 & 0 & 3 & 0.02 & 0.189 \\
\hline Male child & 390 & 0 & 3 & 0.64 & 0.821 \\
\hline Female child & 390 & 0 & 5 & 0.53 & 0.823 \\
\hline
\end{tabular}

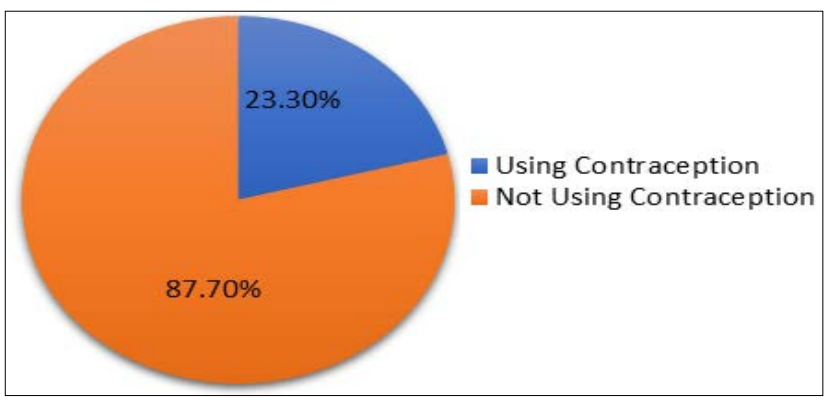

Figure 3.Percentage of Contraceptive Use among Eligible Couples
The total contraceptive use (CPR: Couple Protection Rate) was only $23.30 \%$ which could very well indicate unmet needs in family planning (Figure 3 ).

Contraceptive use significantly differed among couples who only had female child/ children and those who at least had one male child. The contraceptive use in these two groups was $8.5 \%$ and $24.7 \%$ respectively (Figures 4 and 5 ).

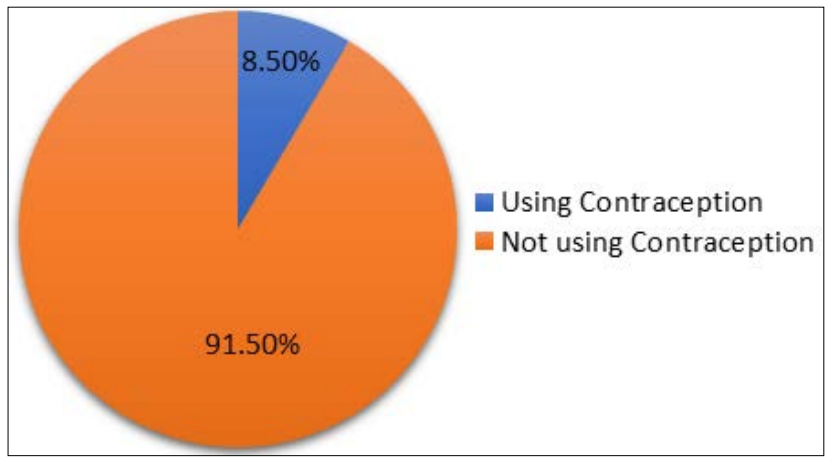

Figure 4.Contraceptive Use among Eligible Couples having only Female Children/ Child

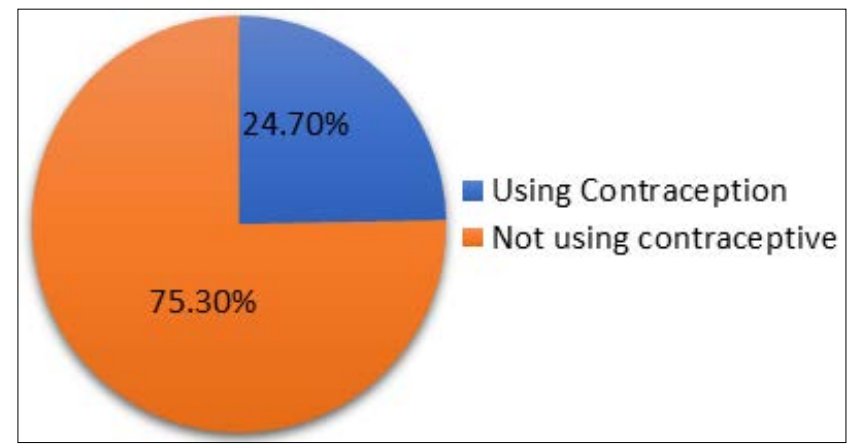

Figure 5.Contraceptive Use among Eligible Couples having at least One Male Child

Tubectomy was the most common method of contraception used by the couples (77.1\%) followed by condoms (16.6\%), IUCD (4.2\%), oral contraceptive (OC) pills (2.1\%) (Figure 6).

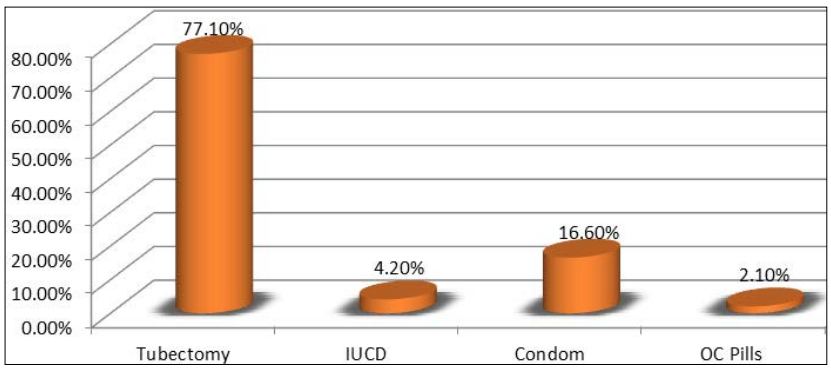

Figure 6.Types of Family Planning Methods Used

The study showed that tubectomy was the main method of contraception among females in the age group of 28-38 years $(48.6 \%)$ followed by $18-28$ years $(32.4 \%)$. IUCD was more prevalent among females in the age group of 18-28 years $(50 \%)$ and among females more than 38 years of age (50\%). Condoms were preferred by females between $18-28$ 
years $(50 \%)$, followed by $28-38$ years $(37.5 \%)$ and by females more than 38 years of age (12.5\%). Oral Contraceptive Pill (OCP) was the favoured method of family planning among females who were between 28 and 38 years of age group (45.8\%) followed by $18-28$ years (35.4\%) and those more than 38 years of age (18.8\%) (Figure 7).

It was found that the age of females at the time of marriage was significantly lower in SC and BC families as compared to NSC ones ( $p$ value $=0.034$ ) (Table 2 ), parity was highly significant of higher age group ( $p$ value $<0.001$ ) (Table 3 ).
Contraceptive use was higher among females in the age group of 28 to 38 years ( $45.8 \%$ ) followed by 18 to 28 years (35.4\%) and females more than 38 years (18.8\%).

This difference in the use of contraceptives among different age groups was highly significant ( $p$ value $<0.001$ ) (Table 4).

The study found that contraceptive use was very less among couples who were having only female children, which was highly significant ( $p$ value $<0.05$, with continuity correction) (Table 5).

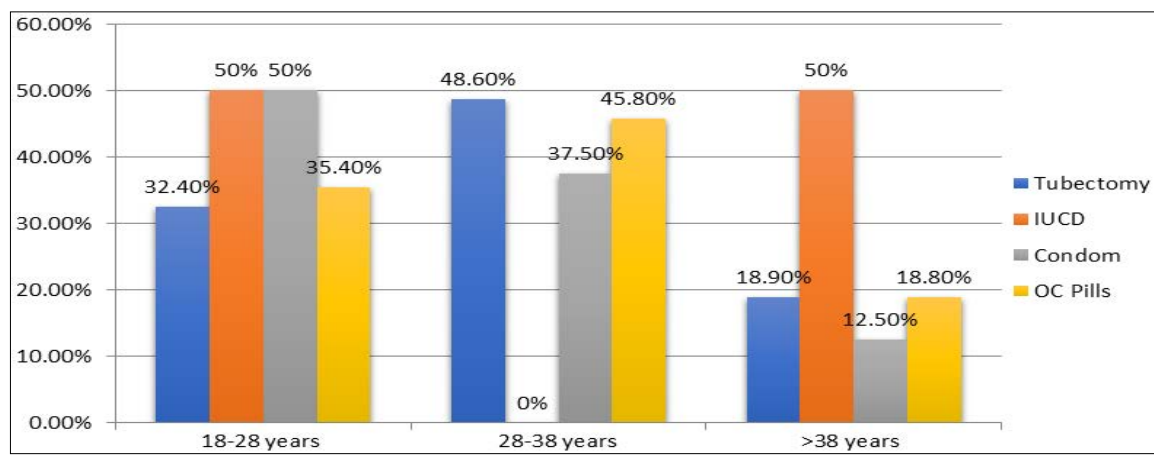

Figure 7.Agewise Use of Contraceptives among Females

Table 2.Association between Type of Family and Sociodemographic Variables

\begin{tabular}{|c|c|c|c|c|c|c|c|c|c|}
\hline \multirow{2}{*}{\multicolumn{2}{|c|}{ Variables }} & \multirow[t]{2}{*}{$\mathbf{N}$} & \multirow[t]{2}{*}{ Mean } & \multirow{2}{*}{$\begin{array}{c}\text { Std } \\
\text { Deviation }\end{array}$} & \multirow[t]{2}{*}{ Std Error } & \multicolumn{2}{|c|}{$\begin{array}{l}\text { 95\% Confidence Interval for } \\
\text { Mean }\end{array}$} & \multirow[t]{2}{*}{$\mathbf{F}$} & \multirow[t]{2}{*}{ p value } \\
\hline & & & & & & Lower Bound & Upper Bound & & \\
\hline \multirow{4}{*}{$\begin{array}{l}\text { Age of females } \\
\text { at the time of } \\
\text { marriage (years) }\end{array}$} & Non-SC & 185 & 26.94 & 5.668 & 0.417 & 26.12 & 27.76 & \multirow{4}{*}{3.398} & \multirow{4}{*}{0.034} \\
\hline & SC & 141 & 25.35 & 5.472 & 0.461 & 24.44 & 26.27 & & \\
\hline & $B C$ & 64 & 25.69 & 6.092 & 0.761 & 24.17 & 27.21 & & \\
\hline & Total & 390 & 26.16 & 5.705 & 0.289 & 25.59 & 26.73 & & \\
\hline \multirow{4}{*}{ Parity } & Non-SC & 185 & 1.25 & 1.274 & 0.094 & 1.06 & 1.43 & \multirow{4}{*}{1.74} & \multirow{4}{*}{0.177} \\
\hline & $\mathrm{SC}$ & 141 & 1.18 & 1.364 & 0.115 & 0.95 & 1.40 & & \\
\hline & $B C$ & 64 & 0.91 & 1.003 & 0.125 & 0.66 & 1.16 & & \\
\hline & Total & 390 & 1.17 & 1.271 & 0.064 & 1.04 & 1.29 & & \\
\hline \multirow{4}{*}{ Stillbirth } & Non-SC & 185 & 0.04 & 0.272 & 0.020 & 0.00 & 0.08 & \multirow{4}{*}{2.577} & \multirow{4}{*}{0.077} \\
\hline & SC & 141 & 0.00 & 0.000 & 0.000 & 0.00 & 0.00 & & \\
\hline & $B C$ & 64 & 0.00 & 0.000 & 0.000 & 0.00 & 0.00 & & \\
\hline & Total & 390 & 0.02 & 0.189 & 0.010 & 0.00 & 0.04 & & \\
\hline \multirow{4}{*}{ Male child } & Non-SC & 185 & 0.67 & 0.817 & 0.060 & 0.55 & 0.79 & \multirow{4}{*}{0.357} & \multirow{4}{*}{0.7} \\
\hline & $\mathrm{SC}$ & 141 & 0.62 & 0.842 & 0.071 & 0.48 & 0.76 & & \\
\hline & $\mathrm{BC}$ & 64 & 0.58 & 0.793 & 0.099 & 0.38 & 0.78 & & \\
\hline & Total & 390 & 0.64 & 0.821 & 0.042 & 0.55 & 0.72 & & \\
\hline \multirow{4}{*}{ Female child } & Non-SC & 185 & 0.59 & 0.849 & 0.062 & 0.47 & 0.71 & \multirow{4}{*}{2.767} & \multirow{4}{*}{0.064} \\
\hline & SC & 141 & 0.55 & 0.890 & 0.075 & 0.40 & 0.69 & & \\
\hline & $\mathrm{BC}$ & 64 & 0.31 & 0.500 & 0.063 & 0.19 & 0.44 & & \\
\hline & Total & 390 & 0.53 & 0.823 & 0.042 & 0.45 & 0.61 & & \\
\hline
\end{tabular}


Table 3.Association between Age Group and Sociodemographic Variables

\begin{tabular}{|c|c|c|c|c|c|c|c|c|c|}
\hline \multirow{2}{*}{\multicolumn{2}{|c|}{ Variables }} & \multirow{3}{*}{$\begin{array}{l}\mathbf{N} \\
1 \\
\end{array}$} & \multirow{3}{*}{$\begin{array}{c}\text { Mean } \\
1.00 \\
\end{array}$} & \multirow{3}{*}{$\begin{array}{c}\text { Std } \\
\text { Deviation }\end{array}$} & \multirow{3}{*}{$\begin{array}{l}\text { Std } \\
\text { Error }\end{array}$} & \multicolumn{2}{|c|}{$\begin{array}{l}\text { 95\% Confidence Interval for } \\
\text { Mean }\end{array}$} & \multirow[t]{2}{*}{$\mathbf{F}$} & \multirow[t]{3}{*}{ p value } \\
\hline & & & & & & Lower Bound & Upper Bound & & \\
\hline \multirow{5}{*}{ Parity } & $<18$ years & & & & & & & \multirow{5}{*}{33.936} & \\
\hline & $18-28$ years & 263 & 0.78 & 1.011 & 0.062 & 0.65 & 0.90 & & \multirow{4}{*}{$<0.001$} \\
\hline & $28-38$ years & 102 & 1.87 & 1.391 & 0.138 & 1.60 & 2.15 & & \\
\hline & $>38$ years & 24 & 2.46 & 1.215 & 0.248 & 1.95 & 2.97 & & \\
\hline & Total & 390 & 1.17 & 1.271 & 0.064 & 1.04 & 1.29 & & \\
\hline \multirow{5}{*}{ Stillbirth } & $<18$ years & 1 & 0.00 & & 0 & & & \multirow{5}{*}{0.298} & \multirow{5}{*}{0.827} \\
\hline & $18-28$ years & 263 & 0.03 & 0.221 & 0.014 & 0.00 & 0.05 & & \\
\hline & $28-38$ years & 102 & 0.01 & 0.099 & 0.010 & -0.01 & 0.03 & & \\
\hline & $>38$ years & 24 & 0.00 & 0.000 & 0.000 & 0.00 & 0.00 & & \\
\hline & Total & 390 & 0.02 & 0.189 & 0.010 & 0.00 & 0.04 & & \\
\hline
\end{tabular}

Table 4.Association between Contraceptive Use and Sociodemographic Variables

\begin{tabular}{|c|c|c|c|c|c|}
\hline \multirow{2}{*}{ Type of Family } & \multicolumn{2}{|c|}{ Contraceptive Use } & \multirow[t]{2}{*}{ Total } & \multirow[t]{2}{*}{ Fisher's Exact Test Value } & \multirow[t]{2}{*}{ p value } \\
\hline & Not using & Using & & & \\
\hline \multirow{2}{*}{ Non-SC } & 160 & 25 & 185 & \multirow{8}{*}{2.611} & \multirow{8}{*}{0.272} \\
\hline & $46.8 \%$ & $52.1 \%$ & $47.4 \%$ & & \\
\hline \multirow{2}{*}{$\mathrm{SC}$} & 122 & 19 & 141 & & \\
\hline & $35.7 \%$ & $39.6 \%$ & $36.2 \%$ & & \\
\hline \multirow{2}{*}{$B C$} & 60 & 4 & 64 & & \\
\hline & $17.5 \%$ & $8.3 \%$ & $16.4 \%$ & & \\
\hline \multirow{2}{*}{ Total } & 342 & 48 & 390 & & \\
\hline & $100.0 \%$ & $100.0 \%$ & $100.0 \%$ & & \\
\hline \multicolumn{6}{|l|}{ Age Range } \\
\hline \multirow{2}{*}{$<18$ years } & 1 & 0 & 1 & \multirow{10}{*}{27.899} & \multirow{10}{*}{$<0.001$} \\
\hline & $0.3 \%$ & $0.0 \%$ & $0.3 \%$ & & \\
\hline \multirow{2}{*}{$18-28$ years } & 246 & 17 & 263 & & \\
\hline & $71.9 \%$ & $35.4 \%$ & $67.4 \%$ & & \\
\hline \multirow{2}{*}{$28-38$ years } & 80 & 22 & 102 & & \\
\hline & $23.4 \%$ & $45.8 \%$ & $26.2 \%$ & & \\
\hline \multirow{2}{*}{$>38$ years } & 15 & 9 & 24 & & \\
\hline & $4.4 \%$ & $18.8 \%$ & $6.2 \%$ & & \\
\hline \multirow{2}{*}{ Total } & 342 & 48 & 390 & & \\
\hline & $100.0 \%$ & $100.0 \%$ & $100.0 \%$ & & \\
\hline
\end{tabular}

Table 5.Association between Contraceptive Use and Only Female Child

\begin{tabular}{|c|c|c|c|c|c|}
\hline \multirow{2}{*}{\multicolumn{2}{|c|}{ No }} & \multicolumn{2}{|c|}{ Only Female Children } & \multirow{2}{*}{ Total } & \multirow{2}{*}{ p value } \\
\hline & & Yes & & & \\
\hline \multirow{3}{*}{ Contraceptive use } & \multirow{2}{*}{ Not using } & 131 & 43 & 174 & \multirow{3}{*}{$\begin{array}{c}0.027 \\
\text { (with continuity correction) }\end{array}$} \\
\hline & & $75.3 \%$ & $24.7 \%$ & $100 \%$ & \\
\hline & Using & 43 & 4 & 47 & \\
\hline
\end{tabular}




\begin{tabular}{|c|c|c|c|c|c|}
\hline & & $91.5 \%$ & $8.5 \%$ & $100 \%$ & \multirow{2}{*}{0.027} \\
\hline \multirow{2}{*}{ Total } & & 174 & 47 & 221 & (with continuity correction) \\
\cline { 3 - 4 } & & $78.7 \%$ & $21.3 \%$ & $100 \%$ & \\
\hline
\end{tabular}

\section{Discussion}

The study found that the maximum number of females in this study were in the age group of 18 to 28 years which might have been due to the rural setting of this study where females are often seen getting married at a relatively lower age as compared to urban areas where females are often educated and working. The mean ratio of female and male children born to 390 eligible couples was 0.53:0.64 (i.e. 828 females per 1000 males). The Population Census of 2011 showed that the population sex ratio in India was 940 females per 1000 males. The child sex ratio of India was 919 as compared to 846 in Punjab. The violent treatment that a girl child suffers at the time of her birth is regarded as the major cause of low female birth ratio in India. ${ }^{11}$ The study found that the age of females in SC and BC families was significantly lower. Similar such finding reported by Indian Express as per the NFHS 4, stated that in 2015-16, the median age at first marriage for women aged 25-49 years is higher among the social category of Others (19.5 years), followed by OBC (18.5 years), ST (18.4 years), and SC (18.1 years). The article stressed that the government needed to counter the disadvantaged women who are economically weak and also those who belonged to SC and ST communities. Females from these communities are married off at a lower age, regardless of the fact that their age for marriage should be 18 years as per the law. The reason for this might be that a girl child is considered a burden and early marriage shifts the responsibility of the girl from her family to her husband's family. Such females are not well educated and generally stay and work at home, hence due to their lack of knowledge and awareness, the legal age has not posed a problem in these communities. Increasing the legal age of marriage to 21 years for females by the government can help curb the menace of early marriage. ${ }^{12}$ Education for all female children should be made mandatory and parents should be made responsible to educate their children, especially the females so as to increase the age of marriage and improve the CPR at later stages.

\section{Conclusion}

The study found that the age of females, parity and number of female children determined the family planning practices. It will be imperative for us to concentrate on major factors like age of females, parity especially female children, and socio-economical class to increase the use of contraceptives among females. Moreover, there is an increased need to promote the use of IUCD, taking into account the advantages of the same, as this study found that only $4.20 \%$ of contraceptive use was with IUCD. The community at large, including those who have completed their families, should be educated about the permanent methods of family planning, especially tubectomy, and bring about the required behaviour change.

\section{Source of Funding: None \\ Conflict of Interest: None}

\section{References}

1. Park K. Demography and Family planning. In: Park's textbook of preventive and social medicine. 21st ed. Jabalpur: Banarasidas Bhanot Publishers, 2011;454, 457, 478.

2. The Economic Times [Internet]. India's population is stabilising as total fertility rate declines across states; 2021 [cited 2021 Jun 1]. Available from: https:// economictimes.indiatimes.com/news/politics-andnation/indias-population-is-stabilising-as-total-fertilityrate-declines-acrossstates/articleshow/79725193. $\mathrm{cms}$ ?from $=\mathrm{mdr}$

3. Office of the Registrar General \& Census Commissioner, India [Internet]. 2011 Census data; 2011 [cited 2021 Jun 1]. Available from: http://www.censusindia.gov. in/2011-Common/CensusData2011.html

4. Kumar R, Singh MM, Kaur M. Dynamics of contraceptive use in a rural community of Haryana. Indian J Med Sci. 1999 May;53(5):201-11. [PubMed] [Google Scholar]

5. Bhattathiry MM, Ethirajan N. Unmet need for family planning among married women of reproductive age group in urban Tamil Nadu. J Family Community Med. 2014;21(1):53-7. [PubMed] [Google Scholar]

6. Muttreja P, Singh S. Family planning in India: the way forward. Indian J Med Res. 2018;148(Suppl):S1-S9. [PubMed] [Google Scholar]

7. Raghavan S [Internet]. World Population Day 2017: 10 challenges of family planning in India; 2021 [cited 2021 Jun1]. Available from: https://www.thehealthsite.com/ news/challenges-of-family-planning-in-india-accordingto-expert-k0717-505175/

8. Osborn JA, Sriram R, Karthikeyan S, Ravishankar SL. A study on contraceptive prevalence rate and factors influencing it in a rural area of Coimbatore, South India. J Family Med Prim Care. 2021;10(6):2246-51. [PubMed] [Google Scholar] 
9. Mestad R, Secura G, Allsworth JE, Madden T, Zhao $\mathrm{Q}$, Peipert JF. Acceptance of long-acting reversible contraceptive methods by adolescent participants in the Contraceptive CHOICE Project. Contraception. 2011 Nov;84(5):493-8. [PubMed] [Google Scholar]

10. World Health Organization [Internet]. Total fertility rate (births per woman) (Health Equity Monitor); 2021 [cited 2021 Jun 18]. Available from: https://www.who.int/ data/gho/indicator-metadata-registry/imr-details/3344

11. Census 2011 [Internet]. Sex Ratio in India; 2021 [cited 2021 Jun 18]. Available from: https://www.census 2011. co.in/sexratio.php

12. The Indian Express [Internet]. Early marriages highest in SC-STs, not law but education will ensure marriages at later age: Experts; 2021 [cited 2021 Jun 18]. Available from: https://indianexpress.com/article/india/earlymarriage-sc-st-girl-education-6574879/ 